\title{
DEVELOPMENT OF A FATTY FILLER RECIPE FOR A NEW TYPE OF WAFER PRODUCTS
}

The article gives an opportunity to develop the technology of fatty filling for waffles and low-calorie wafers by replacing sugar with a mixture of sweet extracts from the leaves of stevia with erythritol. The expediency of regulating the amount of dry matter due to the introduction of dry skim milk whey has been proved. The whey is a raw material component that further enriches the finished product on minerals and vitamins that are healthy for the human body. The possibility of additional introduction of of beta-carotene, as a dye and ascorbic acid, as a stabilizer of fatty wafer fillings has been investigated. In order to improve the quality and safety of finished products, the possibility of using in the technology of fatty fillings for wafer products a new type of confectionery fat of domestic production "Fettifil" has been experimentally confirmed.

Keywords: waffles, waffle products; fat filling for waffles; erythritol; milk serum; stevia; additional vitaminization.

\section{С. А. ПОЛИВАНОВ}

\section{РОЗРОБКА РЕЦЕПТУРИ ЖИРОВОЇ НАЧИНКИ ДЛЯ НОВОГО ВИДУ ВАФЕЛЬНИХ ВИРОБІВ}

У статті наведено можливість розробки технології жирової начинки для вафель та вафельних виробів зниженої калорійності за рахунок заміни цукру на суміш екстракту солодкого з листя стевії з еритротолом. Доведена доцільність регуляції кількості сухих речовин за рахунок внесення сухої молочної знежиреної сироватки, як сировинного компонента, що додатково збагатить готовий продукт на корисні для організму людини мінерали та вітаміни. Досліджена можливість додаткового внесення бета-каротину, в якості барвника та аскорбінової кислоти, в якості стабілізатора жирових вафельних начинок. Експериментально підтверджена можливість використання нового виду кондитерського жиру вітчизняного виробництва "Феттіфіл" у технології жирових начинок для вафельних виробів 3 метою підвищення якості та безпеки готової продукції.

Ключові слова: вафлі; вафельні вироби; жирова начинка для вафель; еритритом; молочна сироватка; стевія; додаткова вітамінізація

\section{Е. А. ПОЛИВАНОВ}

\section{РАЗРАБОТКА РЕЦЕПТУРЫ ЖИРОВОЙ НАЧИНКИ ДЛЯ НОВОГО ВИДА ВАФЕЛЬНЫХ ИЗДЕЛИЙ}

В статье приведена возможность разработки технологии жировой начинки для вафель и вафельных изделий пониженной калорийности за счет замены сахара на смесь экстракта сладкого из листьев стевии с еритротолом. Доказана целесообразность регуляции количества сухих веществ за счет внесения обезжиренной молочной сыворотки, как сырьевого компонента, которая дополнительно обогатит готовый продукт полезными для организма человека минералами и витаминами. Исследована возможность дополнительного внесения бетакаротина, в качестве красителя и аскорбиновой кислоты, в качестве стабилизатора жировых вафельных начинок. Экспериментально подтверждена возможность использования нового вида кондитерского жира отечественного производства "Феттифил" в технологии жировых начинок для вафельных изделий с целью повышения качества и безопасности готовой продукции.

Ключевые слова: вафли; вафельные изделия; жировая начинка для вафель; еритритол; молочная сыворотка; стевия; дополнительная витаминизация.

Introduction. The new products development and the competitive production are important aspects for the successful growth of the company. Today's consumer tastes are quite volatile. Thereby society dictates new social criterion for producers, sets new requirements and tasks, thereby highlighting forming "trends." In this case, the term "trend" describes the problems of our modern nutrition and allows us to focus the attention of health authorities and the developers of new food products on the food habits of consumers. In the field of taste neurobiology, gastrophysics and molecular gastronomy, some research institutes, cooking and food technology schools in Oxford (Great Britain), Dublin, Cork (Ireland), and Dnipro (Ukraine) have recently started working. Research results form a new global trends in the food market [1-3].

According to data provided in the Annual Survey of Food and Health, which are released by the International Food Information Council (IFIC), 36\% of Americans follow a diet, and therefore they develop an aversion to carbohydrates and sugar. Younger consumers (aged 1834) are more likely to stick to a particular diet than people over 35 years old. However, the essence of the problem is in the fact that consumers do not have a proper understanding of proper diet. And only a small part of the population (less than $40 \%$ ) can list the products that benefit the body.
The survey results are interesting for us. According to which $10 \%$ of the contingent correctly believe that protein intake is necessary; $7 \%$ constantly consume vegetables, $4 \%$ - fruits; $5 \%$ supplement the rations with vitamin and mineral complexes.

The provided information illustrates the need for more complete and clear consumer education in nutrition. However, educational activities require good preparation and organization. That is, it has a large part of the time and finances. A simpler, faster and more affordable way is to produce balanced foods that are popular among the population.

Irrefutable is the fact that many of the nutrition trends, came to Europe and other countries of the world from the United States. For example, the maximum decrease in temperature during heat treatment or the promotion of the consumption of products not exposed to heat. Another important factor for public health is the trend of production and consumption of "free" products ("sugar free; fat free; gluten free", etc.).

The development of these trends depends on the country and the social status of supporters of such transitions. At the same time, self-cooking is relegated to the background, and "snacking" is increasingly becoming a substitute for traditional meals during the day.

(C) Polyvanov Y.A., 2019 
We must not forget about the epidemic scale of obesity, which causes serious concern to health authorities in the world, especially in the countries of the Persian Gulf and the United States, where the level of adult obese people exceeds $35 \%$.

A recent WHO recommendation for reducing the consumption of free sugars throughout life for adults and children is an important step for creating ideas of combined, enriched, sugar-free popular products. WHO recommends reducing the consumption of free sugars to $10 \%$ of the total energy consumption and suggests a further reduction in the consumption of free sugars to below $5 \%$ of the total energy consumption [4].

Given the above information, it becomes clear that not all popular products can take into account the full range of "utility factors". However, such a product was singled out by us - these are wafer products that are very popular in many countries of the world and among different strata of the population.

The formulation of the problem in general form and its connection with important scientific or practical tasks. Confectionery is a large group of highcalorie foods that are very popular and in constant demand among children and adults in Ukraine and the world. Analysis of the data on the consumption level of confectionery products in Ukraine confirms that almost all groups of the population prefer flour confectionery products. They include it in their daily diet, as well as in the diet of children in organized groups. The confectionery segment makes up the most significant part of the total confectionery production (more than 50\%) and has a very large assortment. However, despite this, a common shortcoming is their unbalanced composition of nutrients. These products are characterized by a high calorie content, a significant content of fats and carbohydrates, a low protein content and the almost complete absence of vitamin and mineral components.

Vitamin consumption is quite important for building wellness programs related to the rationalization of food rations. Their lack in rations is accompanied by a decrease in the adaptive capacity of the person, entails the development of chronic fatigue syndrome, reduces mental and physical activity, inevitably leads to a decrease in the body's defenses.

Lack of vitamins in childhood and adolescence affects the indicators of physical development, performance, contributes to the development of metabolic disorders, chronic forms of pathologies and prevents the formation of a healthy generation. In some regions, vitamin deficiencies in the diet of children and adults are combined with insufficient intake of macro and microelements [5]. In this regard, the development of technologies for flour confectionery products enriched with vitamins is predicted to be successful in the domestic market and in the world.

Ukraine is among the top 10 countries for consuming sweets. The average consumption of confectionery per one Ukrainian per year is about $15 \mathrm{~kg}$. The greatest demand is for wafers and wafer products, presented on the market with a wide range of commodity items, differing in type, composition, packaging and price. The Ukrainian market of wafers is gradually reviving after a crisis that over a period of which producers have faced a number of problems: increased production costs, reduced purchasing power of citizens, devaluation of hryvnia, the need to change technology production and raw materials, falling production and foreign trade, etc. According to last year's reports of producers of waffle products, an adaptive tendency towards new market conditions, an increase in production volumes, including exports, and a decrease in the import of products from abroad are outlined.

The geographical structure of exports of waffles from Ukraine in 2017, in physical terms, is shown in the diagram (Fig. 1).

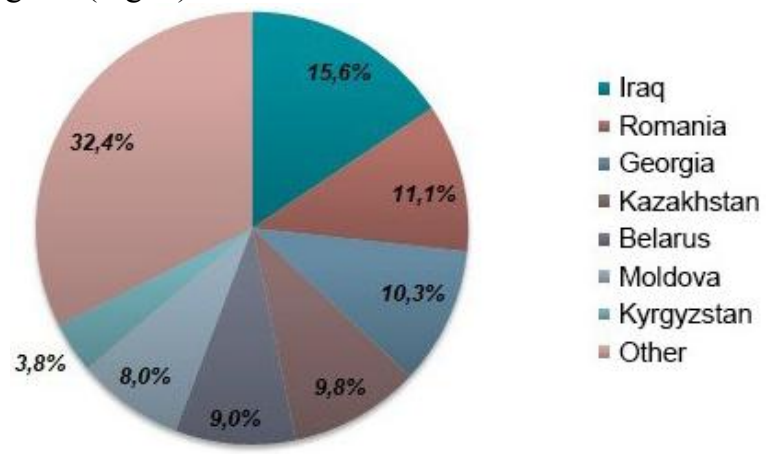

Fig. 1. Diagram of waffle exports geography in 2017

From Fig. 1 it is evident the Ukrainian market of waffles is characterized by high popularity among the countries of the Middle East and former CIS countries.

However, domestic production is the basis of the Ukrainian waffle market and last year its share amounted to $97.4 \%$. Today, the Ukrainian confectionery companies invest money in the development and modernization of production and equipment. The priority remains increasing exports.

The leading confectionery factories modernized the production line. As well as significantly improved manufacturability and knowledge intensity of enterprises. The quality of products of domestic enterprises in many ways does not differ from the foreign ones. Which allows, in fact, to completely oust competitors from other countries. At the same time, the share of foreign trade marks on the Ukrainian market of wafer products at present does not exceed 5\%. It should be noted, along with the general perspective, the conditions for the development of small enterprises are very limited. Most of them require the replacement of obsolete equipment and the introduction of new technologies with a lack of own funds. Therefore, production will continue to be concentrated in the largest corporations. For small firms it is necessary to solve financial problems at the expense of attraction of investments. Because it is precisely the small and medium confectionery business that just forms the internal market of confectionery products.

Thus, investors' attention is becoming more and more prerequisite to be focused not so much on confectionery business projects, but on the support of long-standing enterprises with strong positions in the market, where risks are lower, and the payback periods are shorter. 
Purpose and tasks of work. The aim of the presented scientific research was the development of a formulation of fatty filling for wafer products using natural sweetener of the sweet extract from stevia leaves and a natural sweetener - erythrotol, enriched with vitamins and whey protein proteins; carrying out merchandise quality assessment on organoleptic and physico-chemical parameters.

To achieve this goal, the following tasks were defined:

select the optimal ratio of components in the formulation of fatty filling for waffles, taking into account the organoleptic and physico-chemical quality indicators;

to give a commodity assessment of finished wafer products.

Objects and research methods. The objects of research in this work were:

1) laboratory samples of fatty fillings for wafers, prepared according to the developed recipe from domestic fat "Fettifil", erythritol, sweet extract from stevia leaves, enriched with beta-carotene, ascorbic acid and containing whey;

2) waffle samples prepared with a developed fat filling.

We used standard, generally accepted methods for analyzing the quality of flour confectionery products. The quality of the waffles was evaluated by the combination of organoleptic and physico-chemical parameters. Organoleptic quality assessment of finished products was carried out on a 5-point scale. The quality indicators of the finished waffles were determined in accordance with the requirements of SSTU 4033:2018 "Waffles. General technical conditions" [6].

Presentation of the main research material. Fat masses are thermodynamically unstable systems in which aggregation of solid particles occurs, with a subsequent decrease in the surface of the contacting particles with the dispersion medium. As a result of such processes, the system enters a state with a lower potential energy.

The addition of erythritol and dry whey, as well as stevia extract [7] allows to reduce the sugar content, increase the amount of protein, reduce caloric content, increase biological value, while maintaining high consumer properties. Samples of the wafers filling were prepared with the addition of erythritol, beta-carotene, ascorbic acid, hydrogenated fat "Fettifil" and whey. During this, the properties were examined.

The main criteria for determining the quality of fatty filling were viscosity and adhesive properties. Which commensurate with the control samples prepared according to traditional recipes [8]. According to the existing information, a change in the composition of the fatty filling may lead to a decrease in the effective viscosity due to the destruction of the coagulation structures. There is a possibility of increasing the viscosity of the filling when sugar is completely replaced by other ingredients. There may also be a loss of ductility and fluidity. In this regard, whey has become a component that supports the coagulation structure, and the addition of wafer crumbs improved synergies with the dispersion medium, which was chosen fat "Fettifil" [9]. The amount of fat applied did not differ from the traditional recipe for a fatty wafer filling and amounted to $37 \%$. In comparison with the control samples, the structure of the fatty filling remained strong and the protein-fat systems established good coagulation contacts with the wafer sheet.

It should be noted that the presence of particles of different nature and physicochemical properties (whey, erythritol, sweet extract from stevia leaves, vitamins) influences the kind of the compounds and the strength of the aggregative structures of the structure in different ways. The binding energy of particles in coagulation contacts depends on the kind of the substance, the dispersed phase and the dispersion medium. The more polar one of them, the higher the surface tension at the boundary between them. The greater the polarity difference between the dispersion medium and the particles, the stronger the tendency of particles to aggregate. Therefore, when adding serum, there is an increase in the strength of the contacts, which leads to the strengthening of the structure in the finished product.

The structure formation of fatty masses occurs when they are cooled as a result of crystallization of the dispersion medium - non-lauric-type confectionary fat. The process of structure formation of fat masses during their cooling is accompanied by a decrease in the temperature of the mass and hardening of its structure, i.e. hardening plastic strength. Adhesion is essential in the production of fatty fillings for wafers. Especially in cases where contact is possible between the mass and the surface of the processing machine or strong contact between the used semi-finished products is necessary.

One of the requirements for the quality of waffles according to SSTU 4033:2018 "Waffles. General technical conditions" is a tight fit of the wafer sheet to the filling. Which is determined by the strength of adhesion of these semi-finished products or adhesive bond [6]. In the conditions of semi-industrial production (50 kg of finished products) a good adhesive property of the sheets to the wafer filling was noted. The number of marriages when cutting layered wafer sheets did not exceed the permissible norms. Organoleptic evaluation of finished products was carried out on a five-point scale. This was done according to the method of sensory evaluation "A Not A", according to the following quality indicators: appearance (shape, surface condition, color), structure in a fracture, filling consistency, smell and taste. Analysis of the data showed that samples with the introduction of stevia extract, erythritol, ascorbic acid, beta-carotene, whey are characterized by a more pronounced taste, aroma and a more tender consistency of the filling, because they contain high levels of protein and vitamins. Which are good natural biostimulants of many metabolic processes in the human body [6]

A vitamin such as beta-carotene is essential for the metabolism and maintenance of health. $\beta$-carotene is the most powerful antioxidant and immunomodulator. It strengthens immunity, carries out prevention of 
infectious diseases and neutralizes harmful influences of the environment, stresses, increasing the protective properties of the organism as a whole. After analyzing the existing technology of waffle production, we proposed the possibility of enriching fat fillings with other beneficial vitamin - ascorbic acid. Ascorbic acid (E300) is an organic compound. It has the formula $\mathrm{C}_{6} \mathrm{H}_{8} \mathrm{O}_{6}$. Ascorbic acid is one of the main substances in the human diet. Since it is responsible for the normalization of the functioning of connective tissue and bone tissue. Ascorbic acid performs restorative biological functions and functions of coenzymes of some metabolic processes, is an antioxidant. L-ascorbic acid is an active, restored form of vitamin C. In recent years, it has been widely used as an additive in the formulation of healthy products. The physiological effect of ascorbic acid is quite broad: it acts as an anti-scurvy factor, activates the cells that synthesize collagen, increases immunity and stress, stimulates hemopoiesis, increases the strength and elasticity of the walls of the capillaries, promotes better absorption of iron $[10,11]$.

Lack of ascorbic acid of varying degrees is quite common throughout Ukraine. The concern of physicians with questions of providing a person with a sufficient amount of ascorbic acid throughout life is caused by the fact that it refers to those vitamins, which must be constantly replenished with food. However, the use of modern technologies for processing raw materials leads to a significant decrease in the content of this essential nutrient in finished products. The only possible way to prevent the development of ascorbic acid deficiency is its timely and constant use, adequate prevention, including regular consumption of food products enriched with ascorbic acid. In confectionery products its content is very small. Therefore its use in the technology of popular confectionery products is very important for the recovery of the population. The status of stevia as a global ingredient is generally recognized by leading brands of non-alcoholic drinks, such as "Pepsi-Cola" and "CocaCola" with zero or with a $50 \%$ reduced calorie content. Sweeteners derived from stevia are the fastest growing segment in the market of intensive sweeteners.

According to Leatherhead International, in 2007 their share was only $1 \%$, in 2017 it reached $24 \%$. The largest increase is observed in the United States, $85 \%$ of the market for sweeteners with stevia belongs to the United States. In this country, such components occupy $21 \%$ of the American market of intensive sweeteners.

Numerous research have shown that regular use of stevia reduces cholesterol, improves cell regeneration, coagulates blood, strengthens blood vessels, normalizes the intestinal microflora, stabilizes the functioning of the immune system. Also, the benefits of Stevia and its derivatives can be attributed: good solubility in water; a small dose and the possibility of adding to the product at any stage of production; harmless for long-term consumption [12]. The above properties of steviosid are very valuable, but there are some barriers to its application. When the contents of the supplements above a certain taste threshold, a characteristic nuances taste begins to aftertaste. Therefore, it was necessary to supplement the formulation with an ingredient that is able to correct this disadvantage. This ingredient is erythritol. Erythritol is a polyatomic alcohol. It have a sweetness of 0.7 in relation to sugar, a caloric value of 20 $\mathrm{kcal}$ per $100 \mathrm{~g}$ of product. It has significantly lower caloric content, compared to fructose, with content 399 kcal per $100 \mathrm{~g}$. Thus, it became interesting to analyze the energy value of wafers with fatty filling according to existing and developed technologies (Table 1).

Table 1- Energy value of waffles with fat filling (g/100g)

\begin{tabular}{|l|c|c|c|}
\hline \multirow{2}{*}{ Parameter } & \multicolumn{3}{|c|}{ Waffles with fat filling } \\
\cline { 2 - 4 } & sugar & fructose, stevia & erythritol, stevia \\
\hline Protein & 4,1 & 6,5 & 6,5 \\
\hline Fat & 36,4 & 31,4 & 31,4 \\
\hline Carbohydrates & 58,1 & 53,4 & 36,8 \\
\hline Energy value, kcal & 548,0 & 527,6 & 497,8 \\
\hline
\end{tabular}

Baked wafers, prepared according to the developed recipe, have a pleasant taste and aroma, with an even edge and a clear pattern of the surface, developed porosity [13-15]. And it have a reduced calorific value, compared with the analogue on fructose and control on sucrose. Organoleptic and physico-chemical indicators of the quality of wafers with a new fatty filling are given in table. 2.

Table 2 - Organoleptic and physico-chemical indicators of the quality of wafers with filling

\begin{tabular}{|l|l|l|}
\hline \multirow{2}{*}{$\begin{array}{c}\text { Name of the } \\
\text { parameter }\end{array}$} & \multicolumn{2}{|c|}{ Characteristic and value of the parameter } \\
\cline { 2 - 4 } & \multicolumn{1}{|c|}{ New product } & SSTU 4033:2018 "Wafers. General technical conditions" \\
\hline Taste and smell & Peculiar to the name without foreign tastes and odors & Peculiar to the name without foreign tastes and odors \\
\hline Surface & With a clear pattern. Without blisters, dents and cracks & With a clear pattern. Without blisters, dents and cracks \\
\hline Colour & Light yellow & From light yellow to light brown \\
\hline $\begin{array}{l}\text { The structure in } \\
\text { the fracture }\end{array}$ & $\begin{array}{l}\text { Laminated product consisting of alternating layers of } \\
\text { wafers. Wafer sheets tightly in contact with the filling, } \\
\text { the filling is evenly distributed and does not protrude } \\
\text { beyond the edges }\end{array}$ & $\begin{array}{l}\text { Laminated product consisting of alternating layers of } \\
\text { wafers. Wafer sheets tightly in contact with the filling, } \\
\text { the filling is evenly distributed and does not protrude } \\
\text { beyond the edges }\end{array}$ \\
\hline The form & Flat, rectangular, edges of waffles with a smooth edge & $\begin{array}{l}\text { A variety of flat or volumetric, depending on the shape } \\
\text { of the waffles }\end{array}$ \\
\hline $\begin{array}{l}\text { The taste and } \\
\text { smell of } \\
\text { filling }\end{array}$ & $\begin{array}{l}\text { Sweet, without sensation of cloying, with a slight sour } \\
\text { taste, without foreign tastes and odors. }\end{array}$ & $\begin{array}{l}\text { Sweet with taste and aroma of used raw materials and } \\
\text { flavors, without foreign taste and smell. No feeling of } \\
\text { greasiness. }\end{array}$ \\
\hline Filling color & Plain, cream colour & Monotonous, from white to dark brown \\
\hline $\begin{array}{l}\text { Filling } \\
\text { consistency }\end{array}$ & $\begin{array}{l}\text { Homogeneous without grains and lumps, delicate oily, } \\
\text { easily melting in the mouth, finely dispersed }\end{array}$ & $\begin{array}{l}\text { Homogeneous without grains and lumps, delicate oily, } \\
\text { easily melting in the mouth, finely dispersed }\end{array}$ \\
\hline $\begin{array}{l}\text { Mass of a single } \\
\text { product, g }\end{array}$ & \multicolumn{1}{c}{$25 \pm 1,5$} & No more than 150 \\
\hline $\begin{array}{l}\text { Moisture } \\
\text { content, \% }\end{array}$ & 5,8 & No more than 8,4 \\
\hline
\end{tabular}

Вісник Начіонального Технічного Університету «ХПІ». Серія: Інновачійні

дослідження у наукових роботах студентів, 2019. № 15 (1340) 
The organoleptic evaluation of consumer properties of a new type wafers with a fatty filling, erythrotol, milk serum after 90 days of storage at a temperature of $(18 \pm 3)^{\circ} \mathrm{C}$ and a relative air humidity of $65-70 \%$, in corrugated boxes remained high - taste, crisp properties, delamination ability during the period of storage established by SSTU 4033:2018 did not decrease. And it exceed the organoleptic characteristics of the control sample with a sucrose and analogue with a fructose.

Conclusions and development prospects of this direction. According to nutritional scientists, nutrition should contribute to the adaptation of the human body to adverse environmental conditions. So nutrition should not only satisfy the physiological needs of the body for nutrients and energy, but also improve the health of consumers, and carry out prevention of nutritional diseases.

The risk factors for the development of a number of alimentary-dependent diseases include excessive

\section{Список литературы}

1. Sarığlan M. New Orientations in Gastronomy Education: Molecular Gastronomy. Procedia - Social and Behavioral Sciences. 2014. 14 August. Vol. 143, P. 320-324.

2. Burke R., This H., Kelly A.L. Molecular Gastronomy. Reference Module in Food Science. 2016.

3. Spencea C., Youssef J. Assessing the long-term impact of the molecular gastronomy movement on haute cuisine. International Journal of Gastronomy and Food Science. 2018. Vol. 14. P. 35-44.

4. Tiefenbacher K.F. Chapter Eight - New Products Require New Thinking-Ideas and Examples. The Technology of Wafers and Waffles II. Recipes, Product Development, and Know-how. 2019.

5. Воробьева В.М., Воробьева И.С., Кочеткова А.А., Богачук М.Н., Переверзева О.Г., Подбельская Т.А. Оптимизация микронутриентного состава мучных кондитерских изделий. Питание и Здоровье. 2014, март. С. 74-77.

6. Красина И.Б., Джахимова О.Н., Капаева Е.А. Вафельные изделия для диетического питания. Техника $u$ технология пимевых производств. 2009. № 2. С. 54-56.

7. Официальный сайт компании Stevia. URL: https://stevia.in.ua/ (дата обращения 8.07.2019).

8. Зубченко О.В. Технология кондитерского производства: уч. пос. для студ. ВУЗов. Воронеж. гос. технол. ак, 1999. 432 с.

9. Жир кондитерский "Феттифил" H1 TF- 31 TM "Щедро". URL: http://schedro.ua/ru/products/industry/product/1087/zhirkonditerskiy-fettifil-h1-tf--31 (дата обращения 8.07.2019).

10. Пищевая химия / А.П. Нечаев. С.Е. Траубенберг. А.А Кочеткова и др. изд-е 3-е. испр. СПб. : ГІОРД. 2004. 640 с.

11. Спиричев В.Б. Научное обоснование применения витаминов в профилактических и лечебных целях. Bопросы питания. 2010. № 5. C. 5-14.

12. Федун І.Л., Новицький К.О. Інноваційні можливості природних цукрозамінників в Україні. Сучасні питання економіки і права. 2015. № 6. С. 54-61.

13. Тамазова С.Ю., Першакова Т.В., Купин Г.А., Викторова Е.П. Разработка рецептуры и оценка потребительских свойств вафель с начинкой, обогашенных пишевыми добавками. Научный журнал КубГАУ. 2017. № 127. С. 193-203.

14. Бухкало C.I. Загальна технологія харчової промисловості у прикладах і задачах (інноваційні заходи). 2-ге вид. доп. [текст] підручник. / Л.Л. Товажнянский, С.I. Бухкало, Денисова А.С., І.М. Демидов та ін. - К.: ЦНЛ, 2016. - 470 с.

15. Бухкало С.І. Загальна технологія харчової промисловості у прикладах і задачах (приклади та тести). 2-ге вид. доп.: ч. 2 [текст] підручник. - К.: ЦНЛ, 2018. - 108 с.

consumption of sugar, salt, fat, saturated fatty acids, cholesterol, trans fatty acid isomers. Currently, for the purpose of their prophylaxis, WHO recommends restricting consumption of products containing these nutrients. Unfortunately, flour confectionery also belongs to this product group. In order to level the negative impact of the unbalanced composition and increase the micronutrient density of flour confectionery products, we developed a recipe for the filling of waffles using natural sweetener of the sweet extract of stevia leaves and natural erythrotol sweetener. The filling was enriched with vitamins and whey milk proteins. The work presents the organoleptic and commodity assessment of the quality of the finished product. The optimal ratios of the components in the formulation of the fatty filling for wafers were selected, taking into account the organoleptic and physico-chemical quality indicators, as well as the stability of the conditions of the production process.

\section{References (transliterated)}

1. Sarığlan M. New Orientations in Gastronomy Education: Molecular Gastronomy. Procedia - Social and Behavioral Sciences. 2014. 14 August. Vol. 143, P. 320-324.

2. Burke R., This H., Kelly A.L. Molecular Gastronomy. Reference Module in Food Science. 2016.

3. Spencea C., Youssef J. Assessing the long-term impact of the molecular gastronomy movement on haute cuisine. International Journal of Gastronomy and Food Science. 2018. December. Vol. 14. P. 35-44.

4. Tiefenbacher K.F. Chapter Eight - New Products Require New Thinking-Ideas and Examples. The Technology of Wafers and Waffles II. Recipes, Product Development, and Know-how. 2019.

5. Vorobyova V.M., Vorobyova I.S., Kochetkova A.A., Bogachuk M.N., Pereverzeva O.G., Podbelskaya T.A. Optimization of micronutrient composition of flour confectionery products. Nutrition and Health. 2014. march. P. 74-77.

6. Krasina I.B., Dgahimova O.I., Kapaeva E.A. Waffle wares for a dietary feed. Tekhnika $i$ tekhnologiya pishchevykh proizvodstv. 2009. № 2. P. 54-56.

7. Official website of the company Stevia. URL: https://stevia.in.ua/ (date of request 8.07.2019).

8. Zubchenko O.V. Tekhnologiva konditerskogo proizvodstva uchebniki i ucheb. Posobiya dlya studentov vysshikh uchebnykh zavedeniy. Voronezh : Voronezh. gos. tekhnol. akad, 1999. 432 p.

9. Fat confectionery "Fettifil" H1 TF- 31 TM "Schedro". URL: http://schedro.ua/ru/products/industry/product/1087/zhirkonditerskiy-fettifil-h1-tf--31 (date of request 8.07.2019)

10. Pishchevaya khimiya / A.P. Nechayev. S.Ye. Traubenberg. A.A. Kochetkova i dr. izd-ye 3-ye. ispr. SPb. : GÍORD. 2004. 640 p.

11. Spirichev V.B. Nauchnoye obosnovaniye primeneniya vitaminov v profilakticheskikh i lechebnykh tselyakh. Voprosy pitaniya. 2010. № 5. P. 5-14.

12. Fedun I.L., Novyts'kyy K.O. Innovatsiyni mozhlyvosti pryrodnykh tsukrozaminnykiv v Ukrayini. Suchasni pytannya ekonomiky i prava. 2015. № 6. P. 54-61.

13. Tamazova S.YU., Pershakova T.V., Kupin G.A., Viktorova Ye.P. Razrabotka retseptury i otsenka potrebitel'skikh svoystv vafel' s nachinkoy, obogashchennykh pishchevymi dobavkami. Scientific Journal of KubSAU. 2017. № 127. P. 193-203.

14. Bukhkalo S.I. Zagal'na tehnologija harchovoï promislovosti u prikladah i zadachah (innovacijni zahodi). 2-ge vid. dop. [tekst] pidruchnik. / L.L. Tovazhnjanskij, S.I. Buhkalo, Denisova A.€., I.M. Demidov ta in. - K.: CNL, 2016. -470 p.

15. Bukhkalo S.I. Zagal'na tehnologija harchovoï promislovosti u prikladah i zadachah (prikladi ta testi). 2-ge vid. dop.: ch. 2, [tekst] pidruchnik. - K.: CNL, 2018. - 108 p.

Надійшла (received) 23.05.2019

* The work was performed under the direction of Associate Professor, PhD Kondratiuk N.V.

Відомості про авторів / Сведения об авторах / About the Authors

Поливанов Сzор Андрійович (Поливанов Еzор Андреевич, Polyvanov Yehor Andriyovych) - студент IV курсу кафедри харчових технологій, Дніпровський національний університет імені Олеся Гончара, м. Дніпро, Україна; ОRCID: http://orcid.org/0000-0003-4999-5187; e-mail: mr.egor.pv@gmail.com 